\title{
David Oliver: Is the NHS trying to help or bully social care?
}

\author{
David Oliver consultant in geriatrics and acute general medicine
}

Berkshire

Social care in England has been hit hard by deliberate cuts in local authority funding imposed by the coalition government. ${ }^{1}$ Its funding is not ringfenced from funding for other local authority services, and, unlike NHS care, provision is based on means tested eligibility criteria and is now being severely rationed. ${ }^{2}$ Local authorities must also operate within their means and without the last minute bailouts available to NHS providers, further constrained by the political compromises and short term planning that inevitably arise from local electoral accountability. An estimated 400000 fewer people now receive statutory support than in $2010 .^{3}$ Most social care provision is commissioned from private providers, which have suffered from the impact of Brexit and the living wage on the labour market and their margins. ${ }^{4}$

All of this affects acute NHS provision. Delayed care transfers rose $31 \%$ in $2013-15$ alone, most quickly in social care. ${ }^{5}$ And many patients with complex care and support needs are admitted to acute beds. ${ }^{6}$ Backtracking attempts have been made to plug the funding gap, through targeted initiatives such as the Better Care Fund. But the National Audit Office was clear that this has failed to deliver the reductions in admissions or delayed transfers attached to it as preconditions. ${ }^{7}$

We hear increasing calls to prioritise social care rather than the NHS for new spending. An additional $£ 2$ bn for social care over three years was recently announced ${ }^{8}$ — surely a "well done" for our NHS leaders, altruistically advocating for more social care funding at their own expense. After all, the smaller and less powerful social care sector couldn't seem to win the argument on its own.

Scratch the surface, however, and the new money is heavily skewed towards getting social care to help acute NHS provision and, as winter approaches, to avoid overcrowding and emergency care scandals. This $£ 2$ bn came with government planning guidance emphasising the need to reduce delayed transfers by 2000-3000 a year, with the Care Quality Commission inspecting local authorities against standards for joined-up working with the NHS. ${ }^{910}$
Having a much bigger and more powerful NHS dictating terms is the antithesis of the collaborative approaches we need to embed

Newspaper reports described "fines" for "bed blocking" local authorities. ${ }^{11}$ Simon Stevens, NHS England chief executive, said that funding might be withdrawn from poorly performing areas and that the "laissez-faire approach to integration" hadn't worked-meaning that targets, command, and control were now needed. ${ }^{12}$ Predictably, talk about funding withdrawals and fines went down like a lead balloon. The Local Government Association very publicly withdrew its support for government guidance $^{13}$ on the spending of the additional $£ 2 \mathrm{bn} .{ }^{14}$

We do need to help patients leave hospital sooner, but I find myself sympathising greatly with the Local Government Association. Having a much bigger and more powerful NHS dictating terms is the antithesis of the collaborative approaches we need to embed. Many of the patients I see defaulting into hospital—and becoming "bed blockers" - are there only because of a lack of upstream support in their own homes. Often they've clearly been struggling for a while or had crises requiring a community care response, not an ambulance. Once they're in an acute bed, the door can slam behind them.

The whole credo of social care is centred on personalisation, prevention, and helping people live more independently. Social care is intensely local, with no culture of NHS-style central command. To have the NHS dictate from the centre how the NHS and social care should work together is likely to undermine, rather than build, the collaborative culture we need if patients are to leave hospital sooner.

Competing interests: See www.bmj.com/about-bmj/freelancecontributors/david-oliver.

Provenance and peer review: Commissioned; not externally peer reviewed.

Follow David on Twitter: @mancunianmedic

King's Fund. A short history of social care funding. 11 May 2017. https://www.kingsfund. org.uk/topics/social-care/short-history-social-care-funding 
2 Humphries R. Allocating social care funds: difficult decisions ahead. King's Fund. 5 April 2017. https://www.kingsfund.org.uk/blog/2017/04/allocating-social-care-funds.

3 Humphries R, Hall P, Charles A, Thorlby R, Holder H. Social care for older people: home truths. King's Fund. 15 Sept 2016. https://www.kingsfund.org.uk/publications/social-careolder-people.

4 Weatherley M. Cataclysmic or positive? The impact of the national living wage on social care. Guardian 12 April 2016. https://www.theguardian.com/social-care-network/2016/ apr/12/national-living-wage-adult-social-care.

5 National Audit Office. Discharging older patients from hospital. 26 May 2016. https://www. nao.org.uk/wp-content/uploads/2015/12/Discharging-older-patients-from-hospital.pd. Oliver D. David Oliver: Frailty in acute care. BMJ 2016;358:i5195doi:10.1136/bmj.i5195 National Audit Office. Health and social care integration. 8 Feb 2017. https://www.nao. org.uk/wp-content/uploads/2017/02/Health-and-social-care-integration.pdf.

8 Carter R. Budget 2017: social care gets £2bn funding boost. Community Care 2017:358. www.communitycare.co.uk/2017/03/08/budget-2017-social-care-gets-2bn-funding-boost/

9 Bunn J. £2bn for social care to require hospital focus. Health Serv J 2017;23.
10 Care Quality Commission. CQC to conduct 12 local system reviews of health and social care. 4 July 2017. www.cqc.org.uk/news/stories/cqc-conduct-12-local-system-reviewshealth-social-care.

11 Wheeler C. Social care war as NHS fines 22 councils for bed-blocking. Times 16 July 2017

12 Calkin S, Bunn J. Simon Stevens: "Laissez faire" approach to integrated care has not worked. Health Serv J 2017;6.

13 Department for Communities and Local Government. Policy paper: the allocations of the additional funding for adult social care. 9 March 2017. https://www.gov.uk/government/ publications/the-allocations-of-the-additional-funding-for-adult-social-care.

14 Local Government Association. Councils respond to Government rules around spending of social care money. 4 July 2017. https://www.local.gov.uk/about/news/councils-respondgovernment-rules-around-spending-social-care-money.

Published by the BMJ Publishing Group Limited. For permission to use (where not already granted under a licence) please go to http://group.bmj.com/group/rights-licensing/ permissions 